\title{
THE IMPACT OF THE COVID-19 PANDEMIC ON THE FINANCIAL PERFORMANCE OF PHARMACEUTICAL COMPANIES LISTED ON INDONESIA STOCK EXCHANGE
}

\author{
Ediningsih Sri Isworo*, Satmoko Agung \\ University of "Veteran" National Development Yogyakarta, Yogyakarta, Indonesia \\ *E-mail: sri.isworoediningsih@upnyk.ac.id
}

\begin{abstract}
The COVID-19 pandemic was announced by the Indonesian government on March 2nd, 2020 has an impact on almost all aspects of life. To prevent the COVID-19 pandemic from spreading, the government has adopted the LSSR, CARE, and Vaccination policies. This situation has an impact on companies, for pharmaceutical companies, this is expected to have a positive impact. This study aimed to find out the impact of the COVID-19 pandemic and analyze differences in financial performance as measured by Current Ratio/CR, Debt Ratio/DR, Total Asset Turnover/TATO, Return on Equity/ROE, and Price Earning/PE in pharmaceutical companies listed in Indonesia Stock Exchange 2019-2020. By using a paired sample t-test, the following were found: the financial performance of pharmaceutical companies as measured by CR decreased during the COVID-19 pandemic. Meanwhile, financial performance as measured by DR, TATO, ROE, and PE increased during the COVID-19 pandemic. There was no difference in the financial performance of pharmaceutical companies as measured by CR, DR, TATO, ROE, and PE between before the COVID-19 pandemic and during the COVID-19 pandemic.
\end{abstract}

\section{KEY WORDS}

Current ratio, debt ratio, total asset turnover, return on equity, price earning.

The disease was caused by Coronavirus originated from a group of cases of human pneumonia in Wuhan City, China, in late December 2019. Subsequently, the World Health Organization (WHO) temporarily named the new virus 2019 novel coronavirus (2019-nCoV) on January $12^{\text {th }}, 2020$ and then officially changed it to coronavirus disease 2019 (COVID-19) on February $12^{\text {th }}, 2020$. The disease was caused by the coronavirus continued to spread so that on March $11^{\text {th }}, 2020$, WHO assessed that COVID-19 could be categorized as a pandemic, following the Spanish flu 1918 (H1N1), Asian flu 1957 (H2N2), Hong Kong flu 1968 (H3N2), and Pandemic flu 2009 (H1N1), which caused approximately 50 million, 1.5 million, 1 million and 300,000 human deaths, respectively. In Indonesia, the COVID-19 pandemic was announced by President Joko Widodo on March $2^{\text {nd }}, 2020$. This situation has changed almost all aspects of life. Community activities were limited, activities were carried out with different procedures such as before the pandemic and other changes to keep the pandemic under control and not spread. The initial policy was taken by the government to control the COVID pandemic was the Large-Scale Social Restrictions (LSSR) referring to Law Number 6 of 2019 concerning Health Quarantine and relegated to Government Regulations Number 21 of 2020 concerning LSSR in the context of accelerating the handling of COVID-19. Special Capital Region of Jakarta as the nation's capital implemented LSSR I starting April $10^{\text {th }}, 2020$. In this policy the activities were regulated as follows: Teaching and learning activities were carried out through Distance Learning (DL). Office or workplace activities were temporarily suspended; employees were encouraged to work from home. Religious activities at places of worship have been temporarily suspended. Public places and facilities: it was prohibited to carry out activities with many more than five people in public places or facilities as well as exceptions to activities to meet basic needs which include food, energy, communication, finance, and logistics. Mode of transportation: public and private motorized vehicles were limited to a maximum of $50 \%$ passengers. Online motorcycle taxi services only transported goods. This LSSR activity was also implemented in other cities in Indonesia. The results of the evaluation of the LSSR implementation continued to the 
transition period (June-August 2020) and LSSR II which was set for September $9^{\text {th }}, 2020$ ). Noting that the positive cases of COVID have not decreased, entering 2021 the policy for controlling the COVID-19 pandemic was carried out with the Community Activities Restrictions Enforcement (CARE), Micro CARE, Emergency CARE continuing to CARE Level 3 and 4 (kompaspedia.kompas.id). This policy certainly had an impact on the national, local economy as well as companies as business actors.

Companies need funds to run their business. There are various sources of funds for companies such as owners/shareholders, banks, and the capital market (stock exchange). At the Indonesia Stock Exchange, companies that need funds will meet with parties who have excess funds (investors). Investors when investing, of course, expect a rate of return. Therefore, investors need to be careful in choosing a company for their investment. This is because there are various types of companies listed on the stock exchange, each of which has different characteristics and risks. Among the companies listed on the Indonesia Stock Exchange, pharmaceutical companies may be investors' choice in investing. This was based on the consideration that during the COVID-19 pandemic, the products of pharmaceutical companies were in great demand by the community, the government through the Ministry of Health and the Ministry of Industry continues to encourage the realization of independence and increase the competitiveness of the domestic pharmaceutical industry, in line with Presidential Instruction of the Republic of Indonesia Number 6 of 2016 concerning the Acceleration of the Development of the Pharmaceutical and Medical Devices Industry. Other considerations also need to be considered, namely the company's internal and external factors. External factors of the company for example government regulations, currency exchange rates, inflation rates, natural disasters, and others. While internal factors, for example the company's success in increasing sales and profits, success in developing a business (new projects), and others. Furthermore, the company's success in managing these factors is reflected in the financial statements. With financial statements, the company's financial performance can be assessed.

Furthermore, many studies on financial performance have been carried out although the results were inconsistent, among others: there was no difference in financial performance (Current Ratio, Debt Equity Ratio, Return on Assets, and Total Assets Turn Over) in pharmaceutical companies listed on the Indonesia Stock Exchange. (Doerachman et. al., 2016), there was no significant difference in the Current Ratio and Price Earning Ratio between before and after the COVID-19 pandemic but there was a significant difference in the Debt equity to ratio and the Return on equity ratio before and after the COVID-19 pandemic (Esomar and Christiaty, 2021). Other researchers found that the COVID-19 pandemic had an impact on the decrease in mean stock prices and a decrease in financial performance on the Indonesia Stock Exchange (Rahmani, 2020). This was reinforced by the difference in the mean $\mathrm{JCl}$ before and after the COVID-19 pandemic (Rifa'i et. al, 2020). Taking into account the above, this study aimed to find out and analyze differences in the financial performance of pharmaceutical companies on the Indonesia Stock Exchange in 2019 - 2020. The financial performance referred to in this study was measured by Current Ratio/CR, Debt Ratio/DR, Total Asset Turnover/TATO, Return on Equity/ROE and Price Earning/PE.

\section{LITERATURE REVIEW}

The disease was caused by the Coronavirus originated from a group of cases of human pneumonia in Wuhan City, China, in late December 2019. The disease, which became known as coronavirus disease 2019 (COVID-19), continues to spread to various regions of the world so that the World Health Organization (WHO) finally declared COVID-19 a pandemic. In Indonesia, President Joko Widodo announced a COVID-19 pandemic on March $2^{\text {nd }}, 2020$. The number of COVID-19 sufferers in Indonesia continues to grow, as shown in the cumulative data as of July $4^{\text {th }}, 2021$, as follows:

- Confirmed COVID-19: 2,284,084;

- Recovered: 1,928,274; 
- Under Care: 295,228;

- Died: 60,582 .

Taking into account the data above, various efforts to overcome COVID-19 have been carried out starting from Large-Scale Social Restrictions (LSSR) to the Community Activities Restrictions Enforcement (CARE) and gradual vaccine injections have been and will continue to be carried out by the government, considering that the COVID-19 pandemic has had a wide impact on life, both the economy, socio-humanity as well as culture. The impact of the COVID-19 pandemic in the economic field was perceived both individually and in groups, including companies. In the company, stakeholders (management, creditors, analysts, financial consultants, brokers, investors, governments) can use financial statements according to their interests, for example for evaluation purposes, performance assessment, planning, and others.

Complete financial statements usually include a balance sheet, income statement, statement of changes in a financial position which can be presented in various ways such as, for example: as a cash flow statement, notes, and other statements and explanatory material that are an integral part of the financial statements. A good and accurate financial statement can provide useful information, among others in cash flow assessment, analyzing the use of funds, analyzing changes that occur in sources of funds, lending decisions, investments, etc. Financial statements are generally presented in 2 (two) different time periods so that users can assess whether management performance is better or not. Management performance assessment sourced from financial statements is carried out using financial ratios. Financial ratios serve as a tool used to assess the financial condition and performance of the company, which will provide valuable information about the company's health, financial condition, and profitability. Financial ratios are grouped in ratios: liquidity, asset management, debt management, profitability, and market value ratios (Brigham and Houston, 2019).

Many studies on financial ratios have been carried out, including it was found that there was no significant difference in financial performance as measured by ratios (CR, DER, ROA, and TATO) in pharmaceutical companies listed on the Indonesia Stock Exchange (Doerachman, et. al., 2016); there was no difference in financial performance (CAR, ROA, NPL, and FDR) in Islamic banking on the Indonesia Stock Exchange (Ilham and Thamrin, 2021). The findings were almost the same, namely, there was no significant difference in Current Ratio and Price Earning Ratio between before and after the COVID-19 pandemic but there was a significant difference in Debt equity to ratio and Return on equity ratio before and after the COVID-19 pandemic (Esomar and Christiaty, 2021). Other researchers found that the COVID-19 pandemic had an impact on the decrease in mean stock prices and a decrease in financial performance on the Indonesia Stock Exchange (Rahmani, 2020). This was reinforced by the difference in the mean $\mathrm{JCI}$ before and after the COVID-19 pandemic (Rifa'i et. al, 2020). Meanwhile, the findings that the COVID-19 pandemic has led to an increase in expected credit losses in certain banks and that the profitability of the banking sector in Croatia have decreased significantly due to lower income levels and higher provision rates for non-performing loans (Hladika, 2021) and the finding that (i) COVID-19 has had a negative but short-term impact on stock markets in the People's Republic of China, Japan, South Korea, Italy France, Spain, Germany, and the United States and (ii) the impact of COVID-19 on the stock market had a two-way spillover effect between Asian countries and European countries and the United States (He, et al, 2020).

\section{METHODS OF RESEARCH}

Comparative causal research is an ex post facto type of research, namely the type of research on data collected after the occurrence of a fact or event (Indriantoro \& Supomo, 1999). This research was conducted by comparing the financial performance of pharmaceutical companies in 2019-2020. As we all know, the COVID-19 pandemic that originated in Wuhan China occurred in December 2019 and is still ongoing today. However, this research period was limited to 2019-2020. Where 2019 represented the period before the COVID-19 pandemic and 2020 represents the period during the COVID-19 pandemic. 
The reason for this research was that the COVID-19 pandemic is an event that affected the economy, for that scientific evidence is needed.

The population consists of objects/topics with certain characteristics that were determined by researchers for research and drawing conclusions (Sugiyono, 2015). In this study, the population was pharmaceutical companies listed on the Indonesia Stock Exchange. There were 10 companies listed in pharmaceutical companies. Since the population was small, all members of the population were studied (saturated sampling).

The method of data collection is one aspect that affects the smoothness and success of the research. In the research data was collected by documentation. This method was chosen because the data in this study were secondary data.

The data that has been collected was processed and analyzed descriptively and quantitatively. Descriptive analysis was used to analyze data by describing the data that was collected as it was, without the intention of drawing general conclusions or generalizations (Sugiyono, 2015). Descriptive analysis was carried out by making a table, grouping the data, and then describing it. Quantitative analysis in this study was carried out by first processing data from financial statements into the company's financial ratios as follows:

$$
\begin{aligned}
& \text { Current Ratio }=\frac{\text { Current Aset }}{\text { Current liabilities }} \\
& \text { Debt Ratio }=\frac{\text { Total Debt }}{\text { TotalAssets }} \\
& \text { Total Asset Turnover }=\frac{\text { Sales }}{\text { Total Assets }} \\
& \text { Return on Equity }=\frac{\text { Net Profit }}{\text { Equity }} \\
& \text { Price Earning }=\frac{\text { Price }}{\text { Earning per share }}
\end{aligned}
$$

The next step was testing with paired sample t-test. The decision-making on the t-test for paired samples was based on the level of sig $\alpha=0.05(5 \%)$. If the value of sig. from the research variable $>\alpha(0.05)$ then $\mathrm{H} 0$ was accepted, meaning that there was no difference in financial performance and HA was rejected. Testing with paired sample t-test requires the data to be normally distributed. The normality test of the data was carried out by the Kolmogorov Smirnov statistical test.

\section{RESULTS AND DISCUSSION}

Based on financial statement data from companies listed in the pharmaceutical industry, after calculating the value of the financial ratios, the data was processed. The descriptive data of research variables consisting of CR, DR, TATO, ROE, and PE are as follows.

Table 1 - Descriptive Statistics

\begin{tabular}{|l|l|l|l|l|l|}
\hline $\mathrm{n} / \mathrm{n}$ & $\mathrm{N}$ & Minimum & Maximum & Mean & Std. Deviation \\
\hline CR_19 & 10 & 99.36 & 594.24 & 300.38 & 154.77 \\
\hline CR_20 & 10 & 89.78 & 411.60 & 233.95 & 112.40 \\
\hline DR_19 & 10 & 13.35 & 63.51 & 39.95 & 18.66 \\
\hline DR_20 & 10 & 16.31 & 74.88 & 40.73 & 19.36 \\
\hline TATO_19 & 10 & 0.51 & 1.31 & 0.97 & 0.30 \\
\hline TATO_20 & 10 & 0.51 & 1.81 & 0.98 & 0.38 \\
\hline ROE_19 & 10 & -0.18 & 26.36 & 12.07 & 8.05 \\
\hline ROE_20 & 10 & 0.01 & 28.99 & 13.26 & 9.62 \\
\hline PE_19 & 10 & 0.93 & 55.47 & 21.89 & 17.86 \\
\hline PE_20 & 10 & 0.48 & 124.00 & 35.94 & 38.24 \\
\hline
\end{tabular}

Source: secondary data processed. 
Based on table 1, the following can be described: financial performance in 2019 as measured by the value of I CR had a mean $=300.38 \%$ with a standard deviation $=154.77 \%$. The minimum value of $\mathrm{CR}=99.36 \%$ was experienced by PT Kimia Farma Tbk, while the maximum value of $\mathrm{CR}=594.24 \%$ was experienced by PT Merck Sharp Dohme Pharma Tbk. Meanwhile, in 2020, the mean value of $C R=233.95 \%$ with a standard deviation of $112.40 \%$. The minimum CR value $=89.78 \%$ was experienced by PT Merck Sharp Dohme Pharma Tbk and the maximum $\mathrm{CR}=411.60 \%$ was experienced by PT Kalbe Farma Tbk.

The value of the DR variable in 2019 had a mean of $39.95 \%$ with a standard deviation of $18.66 \%$. The minimum value of $\mathrm{DR}=13.35 \%$ was experienced by PT Industri Jamu and Farmasi Sidomuncul Tbk, while the maximum value of $\mathrm{DR}=63.51 \%$ was experienced by PT Indofarma (Persero) Tbk. Meanwhile, in 2020, the mean value of DR $=40.73 \%$ with a standard deviation of $19.36 \%$. The minimum DR value $=16.31 \%$ was experienced by PT Industri Jamu and Farmasi Sidomuncul Tbk and the maximum DR $=40.73 \%$ was experienced by PT Indofarma (Persero) Tbk.

The value of the TATO variable in 2019 hada mean of $0.97 x$ with a standard deviation of 0.30 . The minimum value of TATO $=0.51 x$ was experienced by PT Kimia Farma Tbk, while the maximum value of TATO $=1.31 \mathrm{x}$ was experienced by PT Tempo Scan Pacific Tbk. Meanwhile, in 2020, the mean value of TATO $=0.98 \times$ with a standard deviation of 0.38 . The minimum TATO value $=0.51 \times$ was experienced by PT Phapros Tbk and the maximum TATO $=1.81 \mathrm{x}$ was experienced by PT Merck Sharp Dohme Pharma Tbk.

The ROE variable value in 2019 had a mean of $12.07 \%$ with a standard deviation of 8.05. The minimum value of ROE $=-0.18 \%$ was experienced by PT Kimia FarmaTbk, while the maximum value of $\mathrm{ROE}=26.36 \%$ was experienced by PT Industri Jamu and Farmasi Sidomuncul Tbk. Meanwhile, in 2020, the mean value of $\mathrm{ROE}=13.26 \%$ with a standard deviation of $9.62 \%$. The minimum value of $\mathrm{ROE}=0.01 \%$ was experienced by $\mathrm{PT}$ Indofarma (Persero) Tbk and the maximum ROE $=28.99 \%$ was experienced by PT Tbk.

The value of the PE variable in 2019 had a mean $=21.89 x$ with a standard deviation of 17.86. The minimum value of $\mathrm{PE}=0.93 \times$ was experienced by PT Merck Sharp Dohme Pharma Tbk, while the maximum value of $\mathrm{PE}=55.47 \times$ was experienced by $\mathrm{PT}$ Indofarma (Persero) Tbk. Meanwhile, in 2020, the mean value of $P E=35.94 \times$ with a standard deviation of 38.24. The minimum value of PE $=0.48 \times$ was experienced by PT Merck Sharp Dohme Pharma Tbk and the maximum PE $=124 \mathrm{x}$ was experienced by PT Kimia Farma Tbk.

Quantitative analysis was conducted to answer the research problem. The results of data processing are shown in the following table.

Table 2 - Financial Performance of Pharmaceutical Companies in 2019-2020

\begin{tabular}{|l|l|l|l|l|}
\hline Financial Performance & 2019 & 2020 & Change & Information \\
\hline CR & 300.38 & 233.95 & -66.43 & Decrease \\
\hline DR & 39.95 & 40.73 & 0.79 & Increase \\
\hline TATO & 0.97 & 0.98 & 0.01 & Increase \\
\hline ROE & 12.07 & 13.26 & 1.19 & Increase \\
\hline PE & 21.89 & 35.94 & 14.04 & Increase \\
\hline
\end{tabular}

Source: Secondary data processed.

Based on table 2 above, it can be explained that in general, the financial performance of pharmaceutical companies as measured by DR, TATO, ROE, and PE has increased, while the financial performance as measured by CR has decreased. The decrease in CR to $233.95 \%$ during the COVID-19 pandemic showed good current asset management because if the CR is too high it is also not good for the company. The explanation of the variables is as follows: during the research period, the financial performance of pharmaceutical companies as measured by $\mathrm{CR}$ was in a liquid condition, meaning that if the company has to pay off its short-term obligations immediately, the company is able to fulfill them. Financial performance as measured by DR showed that in general, the company's debt was less than $50 \%$, meaning that each company's debt was guaranteed to be double the company's assets. The financial performance as measured by TATO also increased, however, with the asset 
turnover, the company would need to make more efforts to increase its turnover. For financial performance as measured by ROE, in general, the company could be said to have good profitability, meaning that the company was able to generate profits for shareholders. In terms of $\mathrm{PE}$, it has also increased, but with a PE value $>10$, investors generally consider the stock price to be relatively expensive. This condition is less attractive to investors. Based on the results of research data processing, the company would need to increase TATO turnover and reduce PE so that the company's overall financial performance becomes better. Various ways can be carried out by the company, for example: to increase sales and cost efficiency using new methods based on technology, information, and communication.

In this study, the object of research was a pharmaceutical company, whose products during the COVID-19 pandemic are predicted to be very needed by the community so that it has an impact on their financial performance. To prove this, the collected data was processed and tested by paired sample t-test. This test requires the data to be normally distributed. The following are the results of the data normality test.

Table 3 - The results of the data normality test on the research variables

\begin{tabular}{|l|l|l|l|}
\hline Variable & Kolmogorov-Smirnov & df & \multicolumn{1}{l|}{} \\
\hline Study & Statistic & 10.000 & $.200^{\circ}$ \\
\hline CR_19 & 0.123 & 10.000 & $.200^{*}$ \\
\hline CR_20 & 0.172 & 10.000 & $.200^{*}$ \\
\hline DR_19 & 0.212 & 10.000 & .129 \\
\hline DR_20 & 0.234 & 10.000 & .200 \\
\hline TATO_19 & 0.161 & 10.000 & $.200^{*}$ \\
\hline TATO_20 & 0.170 & 10.000 & .200 \\
\hline ROE_19 & 0.133 & 10.000 & .200 \\
\hline ROE_20 & 0.137 & 10.000 & .181 \\
\hline PE_19 & 0.221 & 10,000 & .100 \\
\hline PE_20 & 0.364 & & \\
\hline
\end{tabular}

Source: Secondary data processed.

Based on the results of the data normality test with Kolmogorov-Smirnov, the results were obtained where all research variables, namely: CR, DR, TATO, ROE, and PE, both 2019 and 2020 data were normally distributed. Based on the results of the test, to find out whether there are differences in the financial performance of pharmaceutical companies in 2019 - 2020, the data was then processed using a paired sample t-test. The results are presented in the following table.

Table 4 - The results of the paired sample t-test of the financial performance of pharmaceutical companies in 2019 and 2020

\begin{tabular}{|l|l|l|l|l|l|l|l|l|}
\hline \multicolumn{3}{|c|}{$\mathrm{n} / \mathrm{n}$} & \multicolumn{2}{l|}{$\begin{array}{l}\text { 95\% Confidence Interval of the } \\
\text { Difference }\end{array}$} & t & Sig. (2-tailed) \\
\hline Financial Performance & Mean & Std. Deviation & Std. Error Mean & Lower & Upper & & \\
\hline CR_19- CR_20 & 66.432 & 135.189 & 42.751 & -30.277 & 163.140 & 1.554 & 9.000 & 0.155 \\
\hline DR_19-DR_20 & -0.785 & 5.188 & 1.640 & -4.496 & 2.926 & -0.479 & 9.000 & 0.644 \\
\hline TATO_19-TATO_20 & -0.010 & 0.186 & 0.059 & -0.143 & 0.123 & -0.169 & 9.000 & 0.870 \\
\hline ROE_19 - ROE_20 & -1.190 & 5.452 & 1.724 & -5.090 & 2.710 & -0.690 & 9.000 & 0.508 \\
\hline PE_19-PE_20 & -14.044 & 24.212 & 7.656 & -31.363 & 3.276 & -1.834 & 9.000 & 0.100 \\
\hline
\end{tabular}

Source: Secondary data processed.

Based on the results of the paired sample t-test above, the following can be explained: financial performance as measured by CR, DER, TATO, ROE, and PE in pharmaceutical companies was no different before the COVID-19 pandemic and during the COVID-19 pandemic (in 2019 and 2020), meaning that the COVID-19 pandemic had no impact on the financial performance of pharmaceutical companies. The financial performance of pharmaceutical companies as measured by CR had a mean difference of 66,432 but this difference was not significant (t value $\alpha=1.554$, sig $=1.155$ ). This situation showed that there was no difference in liquidity before the COVID-19 pandemic (in 2019) and during the COVID-19 pandemic (in 2020). This showed that the COVID-19 pandemic had no impact on financial performance as measured by CR. The results of this study supported research 
(Doerachman et. al., 2016 and Esomar and Christiaty, 2021). The same thing was found in financial performance as measured by DR, a possible explanation was that the company did not increase/decrease debt in conditions of the COVID-19 pandemic as shown in the DR data, which changes were relatively small. This was because the addition of debt will be risky for the company, especially during the COVID-19 pandemic, the results of this study supported research (Doerachman et. al., 2016). Financial performance as measured by TATO showed no difference. The results of this study supported research (Doerachman et. al., 2016). This situation was inseparable from the LSSR and CARE policies which have limited space for companies and the community to move. It takes time for the company/community to adjust. Companies can make adjustments by developing new products that are needed by the community to overcome the COVID-19 pandemic, making breakthroughs in increasing sales using social media and others. Financial performance as measured by ROE was not different, meaning that the rate of return on profits for shareholders was not different before the COVID-19 pandemic with during the COVID-19 pandemic; this finding was different from the findings (Esomar and Christiaty, 2021). Noting that research data where the ROE of pharmaceutical companies was $12.07 \%-13.26 \%$, it showed that the company's ability to generate profits was good. The financial performance as measured by PE was also no different, however, the PE value of pharmaceutical companies at $21.89 x-35.94 x$ will be considered too expensive by investors. Companies need to increase profits so that PE is considered reasonable. To increase profits, companies can make efficiency by reducing costs that are considered too high or using new technologybased methods that are now growing rapidly.

\section{CONCLUSION}

Based on the results of the study, it can be concluded as follows: the financial performance of pharmaceutical companies as measured by CR decreased during the COVID-19 pandemic. Meanwhile, the financial performance as measured by DR, TATO, ROE, and PE increased during the COVID-19 pandemic. There was no difference in the financial performance of pharmaceutical companies as measured by CR, DR, TATO, ROE, and PE between before the COVID-19 pandemic and during the COVID-19 pandemic.

Taking into account the results of this research, the following can be suggested: financial performance as measured by TATO needs to be improved by increasing sales and cost-efficiency. Increasing sales, for example by developing online sales, using social media, and offering new products to prevent/treat COVID-19. Cost efficiency is carried out by cutting high costs that are less relevant to business operations and collaborating with 3rd parties in terms of product distribution/delivery. These efforts are also expected to be able to increase ROE which in turn will reduce PE so that investors are interested in investing in pharmaceutical companies because they view that their stock prices are not too expensive. The COVID-19 pandemic is still ongoing so that future research is open to be carried out by increasing the research time period or using other performance measures such as quick ratio $(\mathrm{QR})$, profit margin ratio on sales, and others. Future research is also open to be carried out on different groups of companies for example transportation companies.

\section{ACKNOWLEDGEMENTS}

The authors would like to thank the Institute for Research and Community Service, University of Veteran National Development Yogyakarta, Indonesia, which has provided financial support for this research.

\section{REFERENCES}

1. Brigham, Eugene, F and Houston, Joel, F. (2019). Fundamentals of Financial Management $15^{\text {th }}$. Cengage, MA 02210 USA. 
2. Doerachman, Satriya Darma, Tommy, Parengkuan dan Rate, Paulina Van. (2016). Analisis Perbandingan Kinerja Keuangan pada Perusahaan Farmasi yang Terdaftar di Bursa Efek Indonesia pada periode 2011 - 2014. Jurnal Berkala Ilmiah Efisiensi, Volume 16, No. 03.

3. Esomar, Maria J. F dan Chritianty, Restia. (2021). Dampak Pandemi COVID-19 terhadap Kinerja Keuangan Perusahaan Sektor Jasa di BEI. Jurnal Konsep Bisnis dan Manajemen, 7 (2).

4. Ilhamdan Thamrin, Husni, (2021), Analisis Dampak COVID 19 Terhadap Kinerja Keuangan Perbankan Syariah di Indonesia, Jurnal Tabarru': Islamic Banking and Finance, Volume 4 Nomor 1.

5. Indriantoro, Nur dan Supomo, Bambang.(1999), Metodologi Penelitian Bisnis Untuk akuntansi \& Manajemen, Yogyakarta, BPFE.

6. He, Q., Liu, J., Wang, S., Yu, J., (2020), The impact of COVID-19 on stock markets, Economic and Political Studies, 8:3, 228-275.

7. Hladika, Mirjana (2021), Impact of COVID - 19 Pandemic on The Loans Quality, Provisions and Profitability of The Banking Sector, 69th International Scientific Conference on Economic and Social Development - "Sustainability and Post COVID World" - Dubai.

8. Rahmani, AnisaNadya, (2020), DampakCOVID - 19 Terhadap Harga Sahamdan Kinerja Keuangan Perusahaan, Kajian Akuntansi, Volume 21 No.2 September 2020.

9. Rifa'i, Hasan M, Junaididan Sari, Arista Fauzi K, (2020), Pengaruh Peristiwa Pandemi COVID - 19 Terhadaplndeks Harga Saham Gabungan, E-JRA Fakultas Ekonomi dan Bisnis Universitas Islam Malang, Vol. 09 No. 06 Agustus 2020.

10. Sugiyono. (2015). Metodologi Penelitian Bisnis. Bandung: Alfabeta.

11. COVID 19.go.id accesed5 Julit 2021.

12. http: www.idx.go.id, accesed20 Maret 2021.

13. https://kompaspedia.kompas.id/baca/paparan-topik/psbb-hingga-ppkm-kebijakanpemerintah-menekan-laju-penularan-COVID-19 diakses 2September 2021.

14. https://ekonomi.bisnis.com/read/20201022/257/1308478/revolusi-industri-farmasi-ditengah-pandemi-COVID-19, diakses 2September 2021. 